\title{
СРБИСТИ ИЗ РУМУНИЈЕ НА МЕБУНАРОДНИМ НАУЧНИМ СКУПОВИМА У АРАДУ, ТЕМИШВАРУ (РУМУНИЈА) И НИШУ (СРБИЈА) 2005-2018.
}

\begin{abstract}
У првим двема деценијама XXI века у Араду, Темишвару и Нишу одржано је 15 међународних нучних скупова на којима су и србисти из Румуније универзитетски професори, наставници, књижевници и научни истраживачи - саопштавали реферате, студије и друге прилоге из историје, дијалектологије, књижевности, фолклора, топонимије, ономастике, српско-румунског суживота и сл. Радови са ових научних скупова су накнадно били објављени у посебним зборницима или посебним бројевима стручних часописа, а које наводимо овде после сваког поменутог међународног научног скупа.

Кључне речи: аутор, зборник, истраживач, књижевник, научник, научни скуп, писати, професор, рад, србиста, учесник.
\end{abstract}

- Први међународни научни скуп одржан је 11-13. новембра 2005. године на Западном универзитету у Темишвару, а био је насловљен Mozaicul cultural româno-sârb şi general balcanic / Румунско-српски и општебалкански културни мозаик. У радовима који су изложени на скупу је учествовало преко 40 универзитетских професора и научних истраживача из Румуније, Србије, Русије и Немачке.

Радови србиста из Румуније: Стеван Бугарски пише у раду Примери издавачког гусарењ $а$ - између добра и зла о односу издавач-ауторско право, наводећи неке мање познате издавачке подухвате на српском и румунском језику из деведесетих година минулог века. Он наводи примере у којима се „издавачи сналазе као посредници између аутора и читалаца“: Iovan Ducici, Fericire, iubire, femeie, Editura Niculescu, Bucureşti 1994; Daniil Harms, Un spectacol ratat, Editura Paideia, Bucureşti 1997; Nicolae Velimirovici, Învăţături despre bine şi rău, Editura $\Sigma$ opı $\alpha$, Bucureşti 1999 ş.a.; у опширној расправи De la o listă de cuvinte de origine slavă în limba română la un dicţionar de slavisme. Cu referire specială la Dicţionarul slavismelor în limba română

\footnotetext{
1 jiva.milin@yahoo.com

${ }^{2}$ Рад је настао у оквиру пројекта Истраживане културе и историје Срба у Румунији Центра за научна истраживања културе Срба у Румунији.
} 
al lui Stanko Vojvodić / Oд листе словенских позајмица у румунском језику до речника славизама Станка Војводића. Жива Милин полази од спискова словенских позајмица у румунском језику које су у првој половини XIX века саставили Јаков Хинкулов (1840), Јован Стерија Поповић (1847), Јоан Хелијаде Радулеску (1847) и посвећује посебну пажњу Речнику славизама у румунском језику (2002) Станка Војводића; Октавија Неделку у раду Homo balcanicus y комедијама Душана Ковачевића покушава да дешифрује тајну хумора савременог српског комедиографа, истичући да природа његове комике ,почива уз осавремењавање балканског менталитета од homo balcanicus, homo heroicus до homo balcanicus, homo duplex"; у прилогу Tpaгови дендролатрије у називима места (дуб, stejar) Стева Перинац указује на трагове које је обожавање храста оставило у језику, посебно у топонимији. Он наводи називе места у словенским и двема несловенским земљама образозвана од речи дуб и од изведеница на „р“": Србија: Дуб, дубље, Дубравица; Хрватска: Дубашнииа, Дубошевица, Дубрава; Русија: Дубна, Дубовка, Дубровска; Пољска: Dębica, Dęblin, Dabrowa; Rumunija: Dumbrava, Dumbrăveni, Dumbrăviţa, Stejar, Stejărel, Stejăreşti; Мађарска: Домбра́д и др.; у опширној студији Старина Карашевака у Банату виђена кроз призму карашевске топонимије, на основу анализиране топонимске карашевске грађе, Михај Н. Радан закључује да су Карашевци преци првих Словена који су населили Балкан, а који су се касније помешали са приспелим избеглицама из српских крајева и румунским аутохтоним живљем; поводом обележавања 70-годишњице изласка из штампе првог Српско-румунског речника у Краљевини Румуније (Темишвар 1935), Љубомир Степанов доноси прилог Српско-румунски речник кетфељског проте Милана Николића у којем нам даје податке о аутору речника, о намени и употреби речниковој и др.; у заједничком раду О румунском утицају у говору Банатске Црне Горе Зоран Симић и Маца Царан пишу о румунском утицају на лексички фонд српског периферијског говора Петровог Села и Краљевца.

Часопис: „Probleme de filologie slavă. Вопросы славянской филологии. Проблеми словенске филологије”, XIV, Timişoara 2006.

- Следећи међународни научни скуп Dialoguri interculturale. 50 de ani de slavistică timişoreană. Међукултурни дијалози. Пола века темишварске славистике. Межкультурнье диалоги. 50 лет тимишоарской славистики одржан је 2-4. новембра 2007. године такође на Западном универзитету у Темишвару, а радове на скупу излагали су универзитетски професори, научници и научни истраживачи из Румуније, Србије, Русије, Бугарске, Чешке, Мађарске, Аустрије и Немачке. За овај скуп је проф. др Жива Милин припремио књигу Slavistica universitară timişoreană (1957-2007). Dicţionar biobibliografic [Темишварска универзитетска славистика (1957-2007). Биобиблиографски речник], Timişoara 2007. 
Радови србиста из Румуније: у раду Допринос људи из наших крајева разрешавану правописних проблема модернога српског језика Стеван Бугарски пише о доприносу Доситеја (око 1740-1811), Саве Текелије (17611842), Павла Кенгелца (1766-1834), Димитрија П. Тирола (1793-1857) и Јована Стејића (1803-1853) разрешавању проблема српскога првописа. У „закључним разматрањима“ аутор шише овако: „По њиховим делима и делатностима може се оценити да су, не одбацајући, него делимично прихватајући фонетска правописна начела, ипак у коначном опредељењу били за уравнотежени однос фонетског, етимилошког и морфолошког, као присталице умерене струје која је градила књижевни језик и српску граматику на народном језику, на старим списима и на списима савремених водећих књижевника, настојећи да модернизује српску књижевност и приближи је европским културама изображених народа са што мање потреса и губитака“; Славомир Гвозденовић у раду Мотиви фолклора у поезији Васка Попе подробно анализира наведену тему и истиче да „поезију Васка Попе не можемо тумачити до краја ако се не враћамо увек и изнова њеним везама са српским фолклором"; Жива Милин у прилогу Slaviştii din România la simpozioanele sârbo-române de la Vârşeț, Panciova şi Zrenjanin (1970-1974) [Слависти из Румуније на српско-румунским симпозијумима у Вршцу, Панчеву и Зрењанину (1970-1974)] наводи имена и радове слависта из Румуније који су учествовали на првим српско-румунским симпозијумима на почетку седамдесетих година XX века, а чији је организатор био проф. др Раду Флора; Октавија Неделку у раду Kiš vs. Kiš (Aspecte ale receptării) [Киш vs. Киш (Аспекти рецепције)] упоређује два румунска превода романа Гробнииа за Бориса Давидовича Данила Киша штампана у Темишвару: превод Симеона Лазуреануа Criptă pentru Boris Davidovici (1996) и превод Славице и Јона Кармазана Criptă pentru sufletul lui Boris Davidovici (2006); Стева Перинац у раду Прилог о пореклу назива ,копиле“ покушава да образложи могућност да у апелативу копиле „ванбрачно дете“ сагледа корен коп- са значењем „ватра“. Он види то речима: рум. copala, срп. коприва, пољс. kupało, рум. топоним Copalnic и др.; Михај Н. Радан у расправи Терминологија ватре y говрима Карашевака анализира терминологију ватре која у карашевским говорима садржи, с једне стране, словенске лексеме којих нема у другим словенским говорима (про́сит, про́свет; жьк, ка́бус), а, с друге стране, сачуване архаичне лексеме из старословенске језичке баштине (кла́дем, ку́рим, кош, же́жак, и́жа) којима су додате позајмице из румунског, немачког и других језика (рајпели, шпојер); Љубица Рајкић у прилогу Vasko Popa şi Banatul sârbesc [Васко Попа и српски Банат] пише о друштвеним, економским и културним условима у доба између два светска рата који су утицали на песникову еволуцију и, посебно, на његов избор да пише на српском језику; у раду Studierea confruntativă a idiomaticii limbilor rusă şi sârbă [Компаративно проучавање идиоматике руског и српског језика], Маца Царан пише о 
поштовању принципа систематичне анализе у контрастивним проучавањима фразеологије, која има у виду не изоловане фразеологизме, него њихове синонимне и тематске групе.

Часопис: „Probleme de filologie slavă. Вопросы славянской филологии. Проблеми словенске филологије““, XV, Timişoara 2007.

- $\quad$ Поводом 250 година од рођења Саве Текелије (11. август 1761. године), 23-24. септембра 2011. године одржан је у Араду међународни тематски скуп Сава Текелија и Арађани у Организацији Савеза Срба у Румунији. На скупу су излагали своје радове учесници из Србије (Кикинда и Нови Сад), Мађарске (Будимпешта) и Румуније (Арад и Темишвар).

Радови србиста из Румуније: прилог Стевана Бугарског Сава Текелија Арађанин представља сажети приказ животописа великог српског добротвора, правника, писца и доживотног председника Матице српске, који потиче из арадске племићке породице Поповић-Текелија и који је у своје време био истакнута личност у политичком и културном животу Срба у Угарској. О његовој личности Стеван Бугарски пише овако: „Иако највише помињан као задужбинар, дародавац и добротвор, што он и јесте био, Сава Текелија је имао великих заслуга за српски народ, за српску културу и шире, својим деловањем као политичар, историчар, фолклориста, језикословац, писац, колекционар и књигољубац"; у раду Од Текелије до данас у вилајету Поморишја (Пословице и пословичке изреке) Јаворка Марков Јоргован пише о Сави Текелији као сакупљачу српских пословица и пословичких изрека. Она доноси примере таквих пословица забележених на Ферићевој књизи Басне и у Текелијином Дневнику. „Овим је белешкама - сматра аутор - Сава Текелија оставио јединствени документ о времену живота пословица српског језика на Поморишком подручју с краја XVIII века“; Божидар Панић у раду Над књигом Саве Текелије. Утисии и запажања о мемоарском спису „Описаније живота мога“ разматра неколико карактеристичних детаља „у ширем контексту Савиног времена и окружења, што употпуњује слику о ономе о чему Сава пише“, а ти су детаљи: датум Савиног рођења, градња двеју арадских тврђава, Савино школовање у српској и латинској школи у Араду, Текелијина башта, Савино казивање о посети цара Јосифа II Араду и др. Аутор прилога потврђује факсимилом запис Савиног крштења из матичне књиге Текелијине цркве да је датум Савиног рођења 17. август 1761. године; истиче да када Сава пише „о старом граду“ и о „новом граду“ има у виду Леополдинску (стару) тврђаву саграђену 1698-1701. за време владавине Леополда I и Терезијанско-јозефинску (нову) тврђаву саграђену 1763-1783. за време владавине Марије Терезије и Јосифа II; локализује српску школу у порти Текелијине цркве, а латинску школу у Немачкој вароши, при арадској римокатоличкој цркви Светог Антуна Падованског; сматра да Савино казивање о посети цара Јосифа II Араду „има значај сведочанства очевица 
догађаја“" и др.; Љубомир Степанов у прилогу Повеља о додели племства поморишкој породици Јована Поповића Текелије доноси факсимил повеље са записом о проглашењу племства у Пешти 15. јуна 1716. године, препис латинског текста, српски превод и своја запажања о повељи.

Зборник радова: Арад кроз време. Aradul de-a lungul timpului, 13, Tемишвар 2012.

- У Организацији Савеза Срба у Румунији, у оквиру Дана српске културе у Темишвару, одржан је 11-12. новембра 2011. године међународни научни скуп са темом Државотворна идеја трију српских великана: грофа Борђа Бранковића, Доситеја Обрадовића и Саве Текелије, уприличен поводом три значајне годишњице: 300 година од смрти грофа Ђорђа Бранковића (Јенопољ, 1645 - Хеб, Чешка, 1711), 200 година од смрти Доситеја Обрадовића (Чаково, око 1740 - Београд, 1811) и 250 година од рођења Саве Текелије (Арад, 1761-Арад, 1842). За овај скуп је Стеван Бугарски приредио три двојезичне српско-румунске књиге: Гроф Ђорђе Бранковић / Contele Đorđe Branković (Темишвар, 2011), Доситеј Обрадовић / Dositej Obradović (Темишвар, 2011) и Сава Текелија / Sava Tekelija (Темишвар, 2011). На научном скупу одржаном у свечаној дворани Гимназије Доситеј Обрадовић излагали су своје радове универзитетски професори и научни радници из Србије (Кикинда, Ниш, Нови Пазар и Нови Сад), Мађарске (Будимпешта) и Румуније (Темишвар).

Радови србиста из Румуније: Стеван Бугарски у раду Политички тон румунске Хронике Ђорђа Бранковића разматра разлоге који су навели Ђорђа Бранковића да пише на румунском језику историјско дело Cronica slovenilor Iliricului, Mysii cei din Sus şi cei din Jos Mysii [Хроника Словена Илирика, Горње Мезије и Доње Мезије], негде између 1684. и 1688. године. У Хрониции се истичу државотворне намере Бранковића, будући да му је она послужила као основа за сакупљање војске, за писање прогласа словенским народима, за дизање народа на оружје против Турака. Исто тако, истиче се и да је његова трагична судбина (,ухапшен и држан у заточеништву двадесетак година до саме смрти”) у основи везана с политичким садржајем хронике; Адријана Сида Мањеа пише у прилогу Одјек Доситејевог дела међу Румунима о румунским преводима Доситејевог дела, који „не само да су најранији, него су то и први целовити преводи књига, а започети још у Угарској”. Најплоднији преводилац Доситејевих дела на румунски језик био је малобечкеречки парох Димитрије Цикиндеал, који је превео: Sfaturile a înţelegerii cei sănătoase... (Buda, 1802), Adunare de lucruri moraliceşti de folos şi spre veselie (Buda, 1808) и Filosoficeşti şi politiceşti prin fabule moralnice învăţături... (Buda, 1814). Године 1885. Јоан Русу је издао нов, свој превод Доситејевих басни под насловом Fabulele lui Deemetriu Cichindealu în traducere nouă din 
originalul sârbesc ale lui Dositej Obradović (Arad, 1885). Додајмо да је најновији румунски превод басни (али без ннаравоученија) урадио темишварски писац Иво Мунћан у књизи Dositei Obradovici, Fabule (Timişoara 2011); у прилогу Доситеј у Темишвару Љубомир Степанов је себи поставио за циљ „да појасни извесне недоумице и исправи неке тврдње“ у вези са Доситејевим боравком у Темишвару. Полазећи од Доситејеве аутобиографске књиге Живот и прикљученија и на основу мапа Темишвара-Града из средине XVIII века он покушава да установи које време је Доситеј провео у Темишвару, адресу атељеа где је учио капамаџијски занат, ко је био и где је становао капамаџија код којега је учио занат, где је он становао и где се хранио, место кућа угледног темишварског грађанина Јована Муцула и др. Аутор завршава свој прилог овако: „С обзиром да Доситеј тврди: ,При том (тј. при капамаџијском мајстору) сам био годину и по, ходећи по пазари и учећи се шити', следи закључак да је у Темишвару за шегрта дошао почетком 1756, a отишао 27. јула 1757. године“.

Зборник радова: Државотворна идеја тројиче српских великана: грофа Ђорђа Бранковића, Доситеја Обрадовића и Саве Текелије. Зборник радова са међународнога научног скупа, Темишвар, 11-12. новембра 2011. Приредили Стеван Бугарски и Љубомир Степанов, Темишвар 2012.

- У Араду је 22-23. септембра 2012. године одржан међународни тематски научни скуп Текелијино Поморишје, на којем су учествовали научни истрживачи из Мађарске (Будимпешта), Румуније (Арад и Темишар) и Србије (Кикинда и Нови Сад). На скупу је било саопштено 11 радова на најављену тему.

Радови србиста из Румуније: Стеван Бугарски у раду Два Србина Арађана пише о двема мање познатим и рано заборављеним арадским српским личностима. Прва је личност Душан Ђермек (Арад, 1852 - Арад, 1876), библиограф и аутор списа Поглед на данашње стање наме музике и библиографију музичких дела (1874), а друга је личност Андреј Станојев (Батања, 1881 - Арад, 1954), аутор дневника вођеног на мађарском језику (сачуван у рукопису), који је његов унук објавио на мађарском и у преводу на румунски: Napló/Jurnal 1915-1921 (2008); у прилогу Добар део сећања прогутало је време... Јаворка Марков Јоргован пише овако: „Хтела бих да кратким освртом изнесем део рукотворина жена из Поморишја, које сам нашла тражећи их дуж обе моришке обале“. Део тих рукотворина су стари поморишки пешкири о чијим врстама и употреби нам саопштава аутор овога списа; Живко Милин у раду Српскословенски рукописи у Текелијином Поморишју представља нам српскословенске рукописе сачуване у двема књижницама Арадске жупаније: библиотека Арадске епархије и библиотека манастира Ходош-Бодрог. Рукописи су искључиво богослужбене књиге: акатистник, зборник, литургијар, минеј, псалтир, четворојеванђеље и др. Рукописи су настали у XVI и у првој половини XVII века и налазили су се 
извесно време у босанском манастиру Гомионици; у опширном историјском раду Чарнојевићи у Поморишју Божидар Панић пише о богатој племићкој породици Чарнојевић која је у XVIII и XIX веку била угледна породица у Араду. Њен родоначелник је био Михајло Чарнојевић „од Маче“ (око 1680 - 1745), царски чиновник, арадски градски сенатор, са конаком на имању у Мачи и породичном кућом у Араду. Њега су наследили усвојени синови Арсеније $(1716$ - 1766) и његови бројни потомци у Мачи и у Араду и Ђорђе (1720-1759) са породицом у Шиманду. Ова се племићка лоза наставила преко Павла Чарнојевића „од Маче и Киш Оросина“ (1755 - 1840) и Петра Чарнојевића (1810 - 1892), ,феишпана“ (великог жупана) Темишварске вармеђе и краљевског комесара; прилог Дејана Попова Наћвала у доба Саве Текелије могао би бити, ако не део, онда бар подстрек или примарни извор података за будућу монографију Наћвале. У њој је историјски део насеља од његовог првог помена 1333. године до његовог преласка у властелинску породицу Јакшић 1445. године, када су га, вероватно, населили Срби. Од половине XVIII века, а то је већ почетни део Текелијиног доба, забележени су подаци о администрацији, цркви и свештенству и др.; Љубомир Степанов нам представља у раду Семиклушко благо ризницу од 23 златна предмета у тежини од 10 кг, коју је семиклушки становник Недељко-Неца Вујин пронашао у свом дворишту копајући темеље за шупу. Та се ризница данас чува у Музеју историје уметности у Бечу. Аутор описује предмете из наведене ризнице „према стручним оценама историчара“: бокале, посуде, чаше, купе, путире и рог. Проналажењу ризнице и описивању њених предмета претходи у раду многовековна историја Великог Семиклуша, а пропраћају их многобројни покушаји стручњака да одгонетну порекло овог огромног блага; завршићемо приказ радова са овог скупа прилогом Љубомира Шандића Лирско казивање о Арад-Гају у којем аутор приказује историју данашњег Арад-Гаја и његову еволуцију од села Гај до данашњег арадског кварта Арад-Гај.

Зборник радова: Арад кроз време. Aradul de-a lungul timpului, 14, Teмишвар 2014.

- На Филолошком, историјском и теолошком факултету Западног универзитета у Темишвару одржан је између 19. и 21. октобра 2012. године међународни научни скуп Српско језичко наслеђе на мултикултурном подручју Баната, на којем су учествовали универзитетски професори, научници и научни истраживачи из Румуније (Темишвар), Србије (Београд, Крагујевац, Ниш, Нови Сад) и Црне Горе (Никшић). На скупу је било саопштено 20 радова, који би се могли сврстити у следеће домене: 1 . лексика и граматика; 2. језик и култура; 3. етнолингвистика, етимологија, семантика и ономастика; 4. етнографија и 5. писци и књиге.

Радови србиста из Румуније: у раду Споменик српског језика с наших простора у рукопису из 1734. године Стеван Бугарски разматра писмо 
и језик рукописа из Тамишке жупанијске управе Националног архива Румуније који је пре неколико година објавио у двојезичном издању: Андреј Петковић, Поклоњење гробу господњем 1734 / Andrej Petković, Pelerinaj în Ţara Sfântă 1734 (Темишвар 2008). „Закључак је - пише аутор - да је у време настајања рукописа српски језик био развијен, дорастао књижевном изражавању, склон богаћењу првенствено из словенскога језичког фонда, а отворен и за коришћење неологизама ради изражавања одређених специфичних појмова"; Славомир Гвозденовић у раду Лирски дијалог Васка Попе са традищијом сагледава песничко казивање Васка Попе полазећи од фолклора, традиције, митологије и обичаја. „Васко Попа - сматра аутор укршта често митолошке елементе са елементима традиције и фолклора, у истој функцији, дајући нов смисао стиху и песми оригиналну песничку формулу”; Жива Милин у раду Стране речи у говору банатских „Црногораца": немачке, мађарске и румунске наводи позајмице које су продрле у овај периферни српски говор за време хабзбуршке (1718-1867), мађарске (1867-1918) и румунске (1919-) администрације у румунском делу Баната и које су највећим делом сачуване и данас. „Те су речи - пише аутор - ушле у овај периферијски српски говор било преко административних и културнопросветних установа, мас-медија и др., било непосредственим контактом са мултиетничким окружењем"; у прилогу Из живота помало заборављених речи (Етимолошке белешке) Стева Перинац објашњава порекло речи сковердза, иура, субота и мољеи у контексту интердисциплинског проучавања. Он је себи поставио за циљ „да скине вео заборава” са наведених речи које срећемо на простору румунског дела Баната; у заједничком раду Дистрибуција енклитика у карашевским и југозападним косовско-метохијским говорима Радивоје Младеновић и Михај Н. Радан разматрају дистрибуцију енклитика у карашевским говорима у румунском делу Баната и у српским говорима призренско-јужноморавског типа на југозападу Косова и Метохије. Аутори истичу да је за обе говорне области карактеристичан контакт са романским језичким системом. На основу сакупљеног материјала, аутори расправљају о дистрибуцији заменичких и глаголских енклитика; Миљана-Радмила Ускату у раду Прилог упознавању погребних обичаја код Карашевака описује и анализира главне тренутке погребног обичаја код Карашевака и приказује карашевску обредну терминологију. Из ове последње издвајамо: мор'-ћa „смрт”, мрта́ваu, „мртвац”, ла́диц̧а „ковчег”, ро́па „рака”, о́коп „сахрана” и помана „даћа”.

Зборник радова: Српско језичко наслеђе на мултикултурном простору Баната, Темишвар 2013.

- Месна организација Савеза Срба у Румунији је организовала 1314. септембра 2013. године, у оквиру „Дана културе Срба у Араду“, међународни научни скуп Еустахија Арсић, књижевник и мецена, уприличен поводом 170- годишњице смрти прве српске 
списатељице нове српске књижевности. На скупу су читали своје радове историчари, књижевници и истраживачи из Италије (Падова), Румуније (Арад и Темишвар) и Србије (Ириг и Нови Сад). За овај скуп је Стеван Бугарски приредио књигу Eycmaxuja om Арсић, полезна размишьања, Темишвар 2013.

Радови србиста из Румуније: Стеван Бугарски на почетку рада Eycmaхија као личност пише овако: „... списатељ и човек, међутим, два су различита појма, која се не могу, а и не морају у истој личности подударати, бар не увек. Ово је покушај да Еустахију сагледамо као човека, као личност“. Да би сагледао Еустахију као личност, аутор рада доноси неколико карактеристичних момената из њеног арадског живота који је трајао четрдесетак година, од којих издвајамо следеће: после два неуспела брака, удала се за богатог Арађанина Саву Арсића; није живела у кући са свекром и свекрвом, а довела је своје родитеље из Ирига; била је у лошим односима са Савином ћерком Маријом и мужевљевом породицом; од њеног доласка у кућу Арсићевих захладили су се односи између Саве Арсића и Саве Текелије; Сава Арсић је умро 1824. године, а Еустахија му је поставила надгробну плочу тек 1828 . године; све је своје сахранила у порти Текелијине цркве и на надгробним плочама уклесала њихова имена, а њено име нико није накнадно уклесао; у раду Ceћaње на Eустахију Арсић. О седамдесетој годишњици смрти Божидар Панић износи у свом првом делу неколико Еустахијиних биографских података: рођена је 14. марта 1776. године у сремском Иригу; њено девојачко презиме је Цинцић; око 1800. године се удала за арадског градоначелника Саву Арсића; у Араду се посветила сопственом образовању и почела да пише; објавила је свега две књиге: Совјет матерњи предрагој обојега пола јуности сербској и валахијској ... (1814) и Полезнаја размишиљенија о четирех годишьих временех ... (1816); умрла је у Араду, 17. фебруара 1843. године. У другом делу пише о породичној кући Арсићевих у којој је била отворена и извесно време радила арадска Препарандија, о дарохранилници на светом престолу коју је Еустахија 1836. године подарила Текелијиној цркви, о барјаку извезеном златном жицом који је Еустахија подарила гардијском одреду, о препису тестамента Еустахије Арсић који се чува у архиви Текелијоној цркви и др.; Љубомир Степанов доноси у раду Арсићи у Араду неколико података о овој угледној арадској породици: породица Арсић је придошла у Арад када је била основана поморишка граница; Сава, Петров син, је био занатлија и трговац, у више мандата сенатор при градском Магистрату (1791-1796), градски капетан (1796-1813) и градоначелник (1814-1823); склопио је брак са Еустахијом Цинцић из Ирига; Еустахија је у Араду постала мецена српским књижевницима; Сава Арсић и Еустахија Арсић су добили племство 28. марта 1814. Године, а са племством и племићки грб; уступили су своју кућу арадској Препарандији и др.

Зборник радова: Apaд кроз време. Aradul de-a lungul timpului, 14, Teмишвар 2014. 
- У Савезу Срба у Румунији у Темишвару је 11-12. октобра 2013. године био организован међународни симпозијум Црњански у Teмишвару, уприличен поводом 110-годишњице рођења српског књижевника, који је провео детињство у Банату. На скупу су учествовали историчари, књижевници и истраживачи из Мађарске (Деска), Србије (Београд) и Румуније (Арад и Темишвар).

Радови србиста из Румуније: Стеван Бугарски је за овај симпозијум припремио есеј Милош Црњански као личност, са циљем, како сам каже у напомени, „да отвори разговор о Милошу Црњанском, да заинтересује слушаоце приказајући га са мање познате стране“. Већ сам почетак је привукао пажњу свима присутнима, када ја аутор есеја проговорио ове речи: „Милош Црњански је за нас занимљив и значајан као личност. Кажем за нас и мислим на Банаћане, јер је Милош, иако рођен у Чонграду, од малих ногу одрастао у Банату; за њега су места Темишвар, Жомбољ, Кикинда, Бечкерек, Иланча, Итебеј итд. била трајне одреднице”. У наставку аутор износи податке о Милошевом боравку и школовању у Темишвару, где су настали и његови почетни књижевни радови; истакао је његову делатност у новим послератним географско-политичким условима у доба између два светска рата; рекао је понешто о његовој двадесетогодишњој емиграцији у Лондону (1945-1965) и о повратку у Београд, где је провео мирно своје старе дане. А о његовој личности аутор есеја нам вели овако: „У свом зрелом узрасту Милош Црњански је израстао у човека с којим је било тешко и радити и сарађивати. Било је у њему дрскости, надутости, осионости, силеџијства, његово основно расположење увек је било кисело, сумњичаво, иронично, није био ни ведар ни љубазан"; Божидар Панић пише у раду Поморишје у контексту сеоба Милоша Црњанског да његови романи Сеобе (1929) и Друга књига сеоба (1962), ,чине тематску целину - живот српског народа у аустријској Војној граници и сеоба у Русију током XVIII века, са вишеслојним садржајем: историјским, социолошким, психолошким и философским”. Рад је посвећен поморишким Србима који су се Великом сеобом (1690) доселили у Аустроугарску, а након нешто више од полувевековног битисања у аустријској царевини, и понаособ укидања Поморишке војне границе (1741) и развојачења Арада и источног дела границе (1746), одлучили да се одселе у Русију. Прва масовна сеоба отпочела је 1751. године. Дошљаци су се настанили у новоосноване области Нова Србија и Славеносрбија. Аутор истиче у раду да је сеоба у Русију имала за последицу промену демографске слике Поморишја; Адријана Сида Мањеа у раду Милош Црњански на румунском и у Румунији доноси нам податке о рецепцији Милоша Црњанског и његовог дела у Румунији. Први је о њој проговорио Мирко Живковић у књизи Сведочанства о српско(југословенско)-румунским културним и кюижевним односима, Букурешт 1976, стр. 99-132. У претпоследњој деценији прошлога века Издавачка кућа „Критерион” у Букурешту му је објавила романе Сеобе. Дневник о 
Чарнојевићу, 1983; Сеобе. Друга књига (I део), 1985 и Сеобе. Друга књига (II део), 1990. Преводи на румунски: O picătură sânge spaniol, Univers, Bucureşti 1983, преводилац Лидија Токариу; Migraţiile, Editura de Vest, Timişoara 1993, преводиоци Душан Бајски и Октавија Неделку. Поводом три деценије од смрти Милоша Црњанског, 2007. године, Јоца Радин Пејанов је превео тротомни избор из његових дела и објавио у Издавачкој кући Брумар у Темишвару: Lirika Itake i druge pesme / Lirika Itakăi şi alte poezii; Jurnalul despre Čarnojević и Stražilovo. На крају овога прилога ауторка пише овако: „Да Милош Црњански припада којој књижевности на језику широког оптицаја, био би сигурно више превођен од стране самих Румуна. Овако излази да је он Румунима познат углавном колико су га опет Срби дочарали“.

Зборник радова: Црњански у Темишвару. Зборник радова са тематског скупа Темишвар, 11-12. октобар 2013. Приредили Стеван Бугарски и Љубомир Степанов, Темишвар 2014.

- У Араду је 12-13. 2014. године одржан међународни научни скуп Арадска тврђава - логор за Српске интернирие у Првом светском pamy уприличен поводом 100-годишњице од почетка Великог рата. У радном делу скупа су учествовали историчари, књижевници и истраживачи из Мађарске (Будимпешта), Румуније (Арад и Темишвар), Србије (Београд, Нови Сад и Футог). Радови су били представљени на српском и румунском језику.

Радови србиста из Румуније: Миодраг Милин у обимној студији Voluntari sârbi pe frontul românesc din toamna anului 1916 [Српски добровољци на румунском фронту у јесен 1916. године] пише о оснивању Прве српске добровољачке дивизије, о ратним операцијама у Добруџи и доноси списак српских официра и војника које је одликовао румунски краљ Фердинанд. Аутор приказује учешће ратника из Прве српске добровољачке дивизије у крвавим биткама у Добруџи 1916. године. Ова је дивизија бројала скоро двадесет хиљада војника. У жестоким борбама било је убијено, рањено и нестало преко 8.500 војника и официра. Аутор прецизира да се спискови са одликованим српским официрима објављају први пут; у раду Civili şi prizonieri sârbi în lagărul de concentrare Austro-Ungar din Arad 1914-1918 [Цивили и ратни заробљеници Срби у аустро-угарском концентрационом логору у Араду 1914-1918] Божидар Панић пише о монструозном експерименту за масовно истребљење цивила по критеријуму етничке припадности који је спровела Аустро-Угарска за време Првог светског рата. Аутор се осврће на смештај логора, управљање, категорије депортованих, њихов број, епидемије, смртност и др. Посебна пажња је поклоњена гробљима, махом заједничким гробницама без обележја, где су укопани умрли логораши; Љубомир Степанов у раду Арадска тврђава - логор за интерниране Србе током Првог светског рата описује концентрациони логор за истребљење Срба, који је био основан у Араду крајем јула месеца 1914. године у арадској тврђави. Аутор доноси 
слике са колонама интернираца из Босне и Херцеговине, са заробљеним и рањеним српским војницима, са великим бројем деце и жена, са заробљеним и рањеним српским војницима у пратњи наоружаних стражара и др. Сматра се да је у близини тврђаве било сахрањено у заједничким гробницама неколико хиљада Срба мученика. „Намера овога списа - каже нам аутор - јесте да пружи једну целовитију слику о Арадском логору уз помоћ илустрованог материјала - старих разгледница и фотографија из ауторове збирке као и других сведочанстава“; Рад Миодрага Ћурушкина Chestiunea Banatului istoric în raporturile dintre România şi Serbia, în cursul Primului război mondial [Проблеми историјског Баната у односима између Румуније и Србије током Првог светског рата] почиње са подацима о етничком саставу историјског Баната на почетку XX века. У наставку он пише да је главни циљ српског ратовања био стварање нове јединствене државе у коју ће да се укључе историјске провинције Србија, Босна и Херцеговина, Хрватска, Словенија, Срем, Бачка, Банат и Далмација. Настао је спор румунских и српских дипломата око историјског Баната. И на крају, о проблему Баната су пресудиле велике силе на мировној конференцији у Версају 1919. године.

И, на крају, додајмо још да је радни део скупа отпочео Славомир Гвозденовић песмама Гаврило Приничи Србима, на Видовдан и Срби, Гаврилу Принцииу о Видовдану 2014, а завршио Стеван Бугарски написом Тужна песма од Европског рата.

Зборник радова: Арадска тврђава - логор за српске интернирие у Првом светском рату, Арад, 12-13. септембар 2014. Приредили Стеван Бугарски и Љубомир Степанов, Темишвар 2014.

- $\quad$ У новој згради Савеза Срба у Румунуји у Темишвару је 29-30. августа 2014. године био организован међународни научни скуп Радичевићи у Темишвару поводом обележавања 190-годишњице рођења Бранка Радичевића. У радном делу скупа су учествовали књижевници и историчари из Румуније (Темишвар), Србије (Нови Сад) и Хрватске (Вуковар).

Радови србиста из Румуније: Стеван Бугарски у напису $O$ школовању Бранка Радичевића у Темишвару критички разматра истраживања о Бранковом школовању у Темишвару која је започео Павле Поповић 1924. године, а наставили Димитрије Кириловић, Мирко Живковић и Иво Мунћан. Аутор овог списа доказује, на основу сачуване грађе о Темишварском лицеју и његовом одсеку филозофије (1841-1848), да је Бранко завршио одсек филозофије тог лицеја током 1841-1843. године; у спису Гроб Тодора Радичевића y Темишвару Адријана Сида Мањеа пише о Тодору Радичевићу, царинском чиновнику и оцу песника Бранка Радичевића, који је скоро четврт века боравио у Темишвару (1841-1864). Тодор Радичевић је умро у Темишвару и био је сахрањен 22. априла 1864. године. У његовом тестаменту датираном 15. септембра 1863. године је написано овако: „,... а они 80 форинти што остају 
нека ми се смртни крст на гроб подигне. То је моја последња жеља и молим долепотписане сведоке братински да ми ту жељу испуне". Пуне четири деценије нико није бринуо о његовом гробу. Кад је 1905. године дознао о томе Љубомир Лотић, епархијски школски референт у Темишвару, решио је да се посаветује са Србима како би обележили Тодоров гроб. По његовом предлогу био је организован одбор који је био опуномоћен да сакупи прилоге, да приреди забаву у корист повећања фондова, да брине о подизању споменика и да при његовом откривању приреди свечаност. Све је то обављено благовремено, па је 30. октобра 1905. године била организована свечаност откривања споменика; Иван Мунћан у есеју Баснописаи Теодор Радичевић пише да је отац Бранка Радичевића био један од угледних Срба у Темишвару и да су га његове књижевне стазе зближиле са Александром Андрићем (1816-1876) који је 1852. године покренуо у Темишвару лист Световид. У овом листу је Теодор Радичевић објавио осам басана: Мрав и пчела, Ружа и лептир, Славуј и гавран, Зрикавач и пудар, Два петла и кобаџ, Лав и лисица, Овие и јарац и Два лисцуа. „Што се басни тиче, - пише аутор есеја - за разлику од Доситеја, а, можда, сматрајући да је то излишно, Теодор Радичевић им није придавао наравоученија“; Дејан Попов у раду $O$ Темишвару и темимварским Србима из времена Бранковог школовања поставио је себи за циљ да представи „делимичну слику Темишвара и тамошње српске заједнице четрдесетих година XIX века, онако како је Бранко могао видети и доживети, када је дошао да настави школовање у Темишварском лицеју“. Из првог поглавља „О Граду и његовим становницима - бургерима“ дознајемо да је у састав Темишвара улазио Град и три предграђа (Фабрика, Јозефин и Мајуреви), да је у целом Темишвару 1847. године регистровано 18.103 душа, да је Темишвар био „напредна хабзбуршка провинцијска варош“. Даље он пише о Србима у Граду и о њиховом црквеном животу. Аутор завршава свој есеј овако: „Бранкова духовна веза са Градом на Бегеју трајала је до краја живота. Обратна веза никада није престала“.

Зборник радова: Радичевићи у Темишвару, Темишвар, 29-30. август 2014. Приредили Стеван Бугарски и Љубомир Степанов, Темишвар 2014.

- На Западном универзитету у Темишвару одржан је 17-19. октобра 2014. године међународни научни скуп Материјална и духовна култура Срба у мултиетничким срединама и/или периферним областима / Cultura materială şi spirituală a sârbilor din regiunile multietnice şi/sau periferice. Скуп је окупио стручњаке, већином са србистичких и славистичких департмана. То су универзитетски професори, наставници и лектори за српски језик са универзитета у Београду, Брну, Букурешту, Крагујевцу, Нишу, Новом Саду и Темишвару, стручњаци са Балканолошког института, Етнографског института и Института за српски језик у Београду, а и други стручњаци и научни истраживачи из Румуније и Србије. 
Радови србиста из Румуније: Славомир Гвозденовић у раду Српска поезија у Румунији и њени односи са модерном поезијом у Србији, понаособ са поезијом Васка Попе повезује српску поратну поезију у Румунији са модерном српском поезијом и са поезијом Васка Попе. Он сматра да је Васко Попа био значајан ослонац и српској послератној поезији у Румунији. „Авангардизам Васка Попе - пише аутор - није остао без одјека. Јован Чолаковић, Жива Поповић, Чедомир Миленовић, Ђока Мирјанић, Драга Мирјанић, Иво Мунћан, Влада Барзин и други - генерација седамдесетих и почетка осамдесетих пажљиво ће пратити нови лирски говор, чији је главни протагониста Васко Попа“; Саша Јашин, аутор рада Српско средњовековно племство у Банату, у апстракту пише овако: „Историјска повест елитног слоја у Банату који се временски протеже на скоро два века, веома је тешко изложити у ограниченој форми, али је првенствено неопходно доказати легитимитет српског елитног слоја у односу на племство Угарске круне“. Историја банатског племства почиње са деспотом Стефаном Лазаревићем и наставља се Стефаном и Дмитром Јакшићем, челником Радичем Поступовићем, војводом Милошем Белмужевићем, војводом Николом Цреповићем и др. Српско племство је полагало право на поседе све до турских освајања средином XVI века; Јаворка Марков Јоргован радом Лебаи је Божје лице (Обредни хлеб и жито код Поморишких Срба) наставља своја етнолошка истраживања поморишких Срба, код којих „жито и хлеб прате човека током целог живота, а њихово присуство у најразноврснијим ритуалима, магијским обредима и народним вероваењима просто фасцинира“; у раду Живе Милина Породични надимщи Срба у Банатској Црној Гори. Ономатолошки прилог (ХХ век) обрађено је око 350 породичних надимака забележених у селима Банатске Црне Горе у XX веку; Октавија Неделку у компаративном раду Слика војника између дефетизма и патриотизма код Милоша Црьанског и Ливијуа Ребреануа ствара контрастивни осврт на протагонисте романа Дневник о Чарнојевићу и Шума обешених: војника Петра Рајића и официра Апостола Бологе; Михај Н. Радан у раду Последице контаката и/или српско(карашевско)-румунског суживота огледане у говорима Румуна из Алмашке долине (Банат) наводи, у првом делу, значајне моменте из историје Баната и померање становништва у Алмашкој долини, док у другом делу анализира српске и карашевске позајмице у алмашком говору и у топонимији; у раду Миљане Радмиле Ускату Погребна иеремонија код Карашевака и Срба. Неколико сличности и разлике је описан погребни обред код Карашевака и прави се разлика између карашевског и српског обреда. „На основу изнетих примера - пише ауторка - лако се затим може увидети чињеница да постоји знатно више сличности него разлике у карашевском и српском погребном обреду“.

Часопис: Исходишта 1, Темишвар/Ниш 2015.

- На Универзитету у Нишу је 16-17. октобра 2015. године одржан 2. међународни научни скуп Материјална и духовна култура Срба у 
мултиетничким срединама и/или периферним областима на којем су учествовали универзитетски професори и истраживачи из Румуније (Букурешт и Темишвар) и Србије (Крагујевац, Ниш и Нови Пазар).

Радови србиста из Румуније: Стеван Бугарски у раду Светски рат (1914-1918) у међуратној завичајној књижевности Срба у Румунији разматра међуратну књижевност „насталу под свежим осећањима учесника“. У њу је укључио ратне белешке Радивоја Фенлачког (1896-1964), ратне успомене Слободана Костића (1884-1956), дневник Андреја Станојева (18811954), казивања Уроша Ковинчића (1889-1939) о арадском логору и епски спев (,тужна песма од европског рата“) Јоце Огњанова (1886-1965). „По својим особинама - пише аутор - списи су на граници белетристике и документарне прозе, а могу добро послужити и као историјски извори“; у апстракту рада Српско племство из Баната у другим православним земљама Саша Јашин пише овако ,... трагање за очувањем социјалног идентитета одвело је српско племство у друге православне земље, попут Русије, Влашке и Молдавије“. Он помиње сремског деспота Ђорђа Бранковића (1486-1496), ћерке Јована Бранковића Милицу Деспину и Јелену, прва удата за влашког владара Њагоја Басараба (1512-1521), а друга за молдавског владара Петра Рареша (1527-1538; 1541-1546), поморишке официре одсељене у Русију: Петра Текелију из Арада, Јована Хорвата из Куртића, Јована Чорбу из Надлака и др.; Жива Милин у првом делу рада Банатска Црна Гора. Историја. Говор. Ономастика доноси податке о писаним поменима њених данашњих насеља, о могућем времену досељавања Срба на њене просторе, о њиховом пореклу и др. Други део рада је посветио „банатско-црногорском говору“, који је, у ствари, српски архаични, периферијски говор, са незамењеним старим јатом, са бројним фонетичким и морфолошким особинама, са архаичном лексиком итд. Трећи део рада је кратак осврт на ономастику, која је углавном српска, а има у њој и елемената немачког, мађарског и румунског порекла; Саша Митровић је у ономатолошком раду Ocвpm на српску антропонимију у Дунавској Клисури поставио себи за циљ „да прикаже елементе српског антропонимског система у Дунавској Клисури“. За свој рад је изабрао село Мачевић (рум. Măceşti), ,,једино село са 95 посто српског становништва“. Његова анализа антропонима је извршена на основу једног дела инвентара имена из матичних књига рођених и умрлих српске цркве у Мачевићу. У једном од закључака аутор пише: „Након анализе можемо рећи да у Дунавској Клисури најбројнија су идиоглотска традиционална народна имена са својим хипокористицима и изведеницама, а затим, по броју, следе библијска и календарска имена“; у заједничком раду Срби у Букурешту. Општи приказ Октавија Неделку и Лидија Чолевић поставиле су себи за циљ да отпочну истраживње Срба у Букурешту, како оних рођених у Румунији, тако и оних који су се доселили и примили држављанство, па и оних 
који су привремено дошли у овај град и остали у њему. О њима ауторке пишу: „Срби у Букурешту живе на два различита поља, дубоко и нераскидиво испреплетени српско-румунским везама формирујући савез двају светова и култура“. Ауторке сматрају да је неопходно истраживати овај сегмент популације из културолошке перспективе. Њихов је рад подељен на следећа поглавља: 1. „Времеплов“; 2. „Статистички преглед“; 3. „Друштвене организације“; 4. „Школство“ и 5. ,Закључне напомене“; у опширној студији $O$ карашевским и алмашким обичајима и обредима Михај Н. Радан разматра и анализира заједничке елементе у материјалној и духовној култури Карашевака и њихових суседа Румуна из алмашке долине. Овим радом он наставља започета истраживања о карашевско(српско)-алмашким(румунским) међусобним утицајима и прожимањима у области материјалне и духовне култуpe. Из компаративне анализе крсне славе, обичаја из божићног циклуса и пролећних пастирских обичаја код алмашких Румуна и Срба Карашевака, аутор нам нуди неколико закључака. Ево једног од њих: „Са сигурношћу можемо тврдити да су не само бројни елементи из обичајне праксе алмашких Румуна из годишњег циклуса празника, већ у великој мери и структура тих обичаја и празника, позајмљени и укорењени у доба симбиозе аутохтоног средњовековног словенског живља (истог типа као и словенски живаљ у Карашкој долини) са придошлим румунским избеглицама из Ердеља и Олтеније и, евентуално (али мало вероватно) са аутохтоним румунским алмашким становништвом“; Миљана Радмила Ускату у компаративној студији Сличности у свадбеном обичају Карашевака и румунских Алмажана - доказ о карашевско-алмашклом суживоту у прошлости упоређује и детаљно анализира свадбени обичај и свадбену терминологију код Карашевака и Алмажана и сличности међу њима. За ову анализу она је користила из своје докторске дисертације део посвећен свадбеном обичају код Карашевака, рад румунског слависте Емила Петровича Folclorul din Valea Almăjului [Фолклор из Алмашке долине] (1935), као и део своје грађе сакупљене у алмашком насељу Далбошец. У првом делу студије доноси податке из историје карашевских и алмашкких насеља, а затим описује свадбене обичаје: прошење-прошња, капару и свадбу. Студија се завршава овако: „Може се, дакле, закључити да су те велике сличности резултат суживота Карашевака и садашњих алмашких Румуна током средњег века, чији је крајњи резултат асимилација карашевског од стране румунског живља у долини Алмажа“; рад О првом српско-румунском речнику кетфељског проте Милана Николића, чији се аутор Љубомир Степанов упокојио пред сам нишки скуп, био је објављен накнадно у радовима скупа.

Часопис: Исходишта 2, Темишвар/Ниш 2016.

- На Западном универзитету у Темишвару је 14-16. октобра 2016. године одржан 3. међународни научни скуп Материјална и духовна култура Срба у мултиетничким срединама и/или периферним 
областима / Cultura materială şi spirituală a sârbilor din regiunile multietnice şi/sau periferice на којем су учествовали универзитетски професори, научници и истраживачи из Бугарске (Софија), Румуније (Букурешт, Решица и Темишвар), Русије (Москва), Србије (Београд, Крагујевац, Ниш и Нови Сад) и Чешке (Брно).

Радови србиста из Румуније: Саша Јашин је свој рад Епископ темишварски племенити Петар (Петровић) (1786-1800) посветио темишварском архијереју Петру (Петровићу) за којега пише да је био ,један од најобразованијих и најслободоумнијих личности Срба у Темишвару на прелому XVIII и XIX века“. Био је именован за администратора Карловачке митрополије после упокојења митрополита Мојсеја Путника и један од кандидата за карловачког митрополита. Његово последње значајно остварење било је отварање Богословског течаја у Темишвару 1800. године. Аутор не наводи годину његовог рођења, а прецизира да се упокојио 23. децембра 1800. године и да је био сахрањен у крипти темишварске саборне цркве; рад Живе Милина Темишварски слависта Чезар Апреотесеј и његови радови о српско-румунским културним везама је посвећен темишварском слависти, ванредном универзитетском професору др филологије Чезару Апреотесеју (1922-1989), члану-оснивачу Темишварске филијале Удружења слависта у Румунији и вишегодишњем њеном председнику. У темишварском униврзитетском животу био је професор, научни истраживач и културно-просветни радник. Сарађивао је радовима и чланцима у локалним и централним листовима и часописима. Значајни су његови радови из домена румунскосрпских културних и лингвистичких веза; Саша Митровић је наставио своја ономатолошка истраживања и овога пута објавио један њихов део у раду Деривачија српских мушких имена у Дунавској Клисури. Аутор третира у њему јединствене и сложене, продуктивне и мање продуктивне суфиксе помоћу којих се стварају мушка имена у српском језику. Он прецизира да „значење личног имена даје корен од којег је име створено, а не суфикси који су само граматичка средства за стварање нових речи; у заједничком раду Срби у Букурешту - идентитет Октавија Неделку и Лидија Чолевић разматрају „стање Срба у Букурешту данас, које се реално разликује од стања у некој од претходних деценија“. Ауторке рада сматрају да Букурешт као мултикултурна средина нуди нове моделе у формирању идентитета српске заједнице. За Србе у Букурешту је карактерстичан „двојни идентитет“ припадности и егзистирања. „Хармонична коегзистенција Срба и Румуна у Букурешту данас - пишу ауторке - мотивисана је лакоћом премошћавања културне баријере уз помоћ познавања оба језика, уз помоћ цркве и православља, као и осећањем у свакодневици“. Ауторке сматрају да су овим радом „отвориле тему положаја Срба у Букурешту у новијој историји, колективног идентитета српске заједнице и њиховој свести о припадности локалној заједници“; Својим радом Циркуларни протокол Православне српске парохије у Наћва- 
ли (1816-1834) Дејан Попов наставља истраживања црквеног и друштвеног живота Срба у Горњем Банату у првој половини XIX века. „Циркуларни протоколи - пише аутор - представљају, претежно због разноврсности тематике, драгоцену, и још увек недовољно искориштену грађу о црквено-народном животу подручја на којем су настали“. Аутор описује наћвалски циркуларни протокол, пише о потписницима окружница, о пастирским посланицама, о званичним објавама, о упутствима (правилима) за свештенике и за вођење црквене администрације, итд. У закључку он пише овако: „Окружнице, саопштења и упутства уписана у Циркуларном протоколу наћвалске парохије, а разаслате током осамдесетогодишњег раздобља у првој половини XIX века, представљају драгоцену збирку разноврсних информација које се као примарни или најчешће комплементарни извор могу користити при проучавању црквеног и друштвеног живота Срба у Горњем Банату“; Михај Н. Радан пише у прилогу $O$ пореклу карашевске ковачке терминологије у говорима Карашева и Клокотича о ковачком занату, који је данас при издисају, и о његовој терминологији у карашевској енклави. Аутор наводи имена ковача у карашевским насељима, ковачке термине са словенскикм кореном, позајмице из страних језика, наводи неке радње, обреде и веровања итд. У закључку аутор приказује следећу слику карашевске ковачке терминологије: термини словенског порекла чине $53,9 \%$, а страног порекла 46,09\%; у раду Карашевска свадба данас - обичаји, ритуали и юихова значена (симболистика) Миљана Радмила Ускату пише како се код Карашевака „неки обичају и данас строго примењују, али, на жалост, многи ритуали и обреди из прошлости су заборављени и не врше се више. Неки од старих обичаја су дубоко урезани у карашевски менталитет, а такви се још чувају“. Ауторка лако прелази преко предсвадбених обичаја, као што су говор/турвин, прошење-прошњ а и капара (веридба) и детаљно објашњава свадбу. У прошлости је свадба код Карашевака трајала три дана и одржавала се у кући, од седамдесетих година прошлог века до двехиљадите године се одржавала у шатору испред куће, прве недеље код младе, а друге недеље код младожење, а данас се одржава у ресторану или дому културе. Миљана Радмила Ускату завршава свој рад овако: „Нажалост, као што се може видети из приказаног, упркос подсвесном отпору, бројни ритуали и обреди су већ нестали или су пред издисајем, а у таквој неизбежној ситуацији важно је да они, док су још живи у колективном памћењу Карашевака, макар буду прибележени и тако отргнути од нестанка без трага“; Благоје Чоботин, у свом раду Имена српске деце крштене у српској православној иркви у Кетфељу током XIX, $X X$ и $X X I$ века, поставио је себи за циљ да представи и анализира имена која су православни верници из Кетфеља давали својој деци приликом крштења. Након исписивања имена из матичних књига, аутор закључује да су у деветнаестом и првој половини двадесетог века, при крштењу деци давана стара српска класична имена, у првим деценијма и средином двадесетог века се 
појављају нова имена, од друге половине двадесетог века појављују се само новија српска, али и румунска имена. Све до педесетих година двадесетог века давала су се имена православних светитеља. Као и у другим местима, и у Кетфељу срећу се „имена парови“ или „парна имена“. Аутор још констатује да је у трећем миленијуму најмање српске деце.

Часопис: Исходишта 3, Темишвар/Ниш 2017.

- На Универзитету у Нишу је 13-15. октобра 2017. године одржан 4. међународни научни скуп Материјална и духовна култура Срба у мултиетничким срединама и/или периферним областима на којем су учествовали универзитетски професори и истраживачи из Бугарске (Софија), Румуније (Букурешт, Решица и Темишвар) и Сpбије (Београд, Крагујевац, Ниш и Нови Сад).

Радови србиста из Румуније: Иван Бирта у првом делу рада Срби и румунске кнежевине у светлу црквенословенскога рукописа из XVII века пише о миграцији Срба у Влашку и у Молдавију. Миграцију су предводили калуђер Никодим Грчић, оснивач првих влашких манастира Водице и Тисмане, и бивши сремски деспот Максим Бранковић, касније влашки митрополит у првој деценији XVI века. „Анализа српске миграције при крају средњег века - пише аутор - доказује да су већ тада Срби неговали општеевропски хришћански концепт, који је био подржан и уважен од тадашњих румунских власти". У другом делу он описује, транслитерира, преводи на српски и тумачи два румунска црквенословенска рукописа из XVII века: Повељу Могиле Војводе (1620) и Предиковање верницима (1609); у прилогу Митрополит нишки и епископ темишварски Георгије Поповић Саша Јашин пише о темишварском јерарху Георгију Поповићу (1745-1757) за којега каже да је остао „запамћен у историји Епархије темишварске као један од највећих ктитора. Његов пастирски рад и градитељски подухвати, поред културне делатности, сврставају га у ред најзначајнијих личности у Банату у XVIII веку“. Споменимо да је за време његовог управљања Темишварском епархијом била изграђена епископска резиденција и саборни храм Вазнесења Господњег (1745-1747). Дознајемо од аутора да је Георгије Поповић роћен 1701. године у Старом Влаху, да је био митрополит нишки и белоцрквански, да је 1737. године прешао у Аустрију и одсео у Сремским Карловцима, да је 1745. године био именован за епископа темишварског, да је преминуо 1757. године и био сахрањен у Саборној цркви; у раду Издавачка кућа „Критерион “ и српска књижевност Октавија Неделку расправља о издавачкој кући Критерион у Букурешту, за коју каже да је била „културна институција, атипична за седамдесете-осамдесете године прошлог века, будући да је омогућила афирмацију књижевности мањина у Румунији на матерњем језику, те на тај начин промовисала писце који припадају различитим етничким групама које живе вековима на румунском тлу“. Октавија Неделку, која је и сама од 1984. до 1991. године била уредник у колективу српске редакције 
у овој издавачкој кући, расправља о књигама на српском језику које је ова издавачка кућа објавила у својем четвртвековном постојању (1970-1994), а њихов је број 222. Посебно је важан, за љубитеље и истраживаче у домену српске књижевности у Румунији, списак Издања на српскохрватском језику у издавачком предузећу Критерион (1970-1994); Октавија Неделку и Лидија Чолевић су аутори рада Срби у Букурешту (3). Српски кюижевници - дипломате у Букурешту : Јован Дучић, Иво Андрић и Милан Ракић, у којем се евоцира део дипломатске каријере наведених српских књижевника у Букурешту. „Њихово дело - пишу ауторке - осим литерарне вредности, драгоцено је у историографији и европској дипломатији“. Ауторке доносе бројне податке о тројици великана српске књижевности који су се у различитим периодима прошлог века (1915-1940) налазили у дипломатској мисији у Букурешту: Милан Ракић (1876-1938) од 26. јануара 1915. године до 2. децембра 1917. године; Иво Андрић (1892-1975) од 1921. до 1922. године; Јован Дучић (1871-1943) од 12. новембра 1937. до 31. маја 1940. године; Дејан Попов у раду Српски хорови и певачка друштва у Темишвару (1836-2016) приказује српске хорове и певачка друштва у Темишвару, чија се активност непрестано одвија „почев са деловањем хора Српске саборне цркве 1836. године, па све до данашњих дана“. Сем црквених хорова ту су и Српска певачка дружина (1867-1947), Слога (1922-1947), Зора (1903-1947) и др. Аутор сврстава њихово деловање у пет периода; у заједничкој студији Реликти паганског порекла у карашевским верским обредима Михај Н. Радан и Миљана Радмила Радан Ускату пишу у апстракту овако: „... још увек су многи стари обичаји очувани и данас још увек живе у колективном памћењу Карашевака, а бројни су они чије порекло треба тражити у претхришћанској, паганској словенској баштини“. Аутори су себи поставили за циљ да у тим сачуваним обичајима разоткрију, опишу и анализирају елементе паганског, предхришћанског порекла. Они анализирају обреде и ритуале везане за Тр́nи дан (Бадњи дан) и Бо́жић', сла́ве̨ье/сла́виње (кућна слава), ко́мкање (обред причешћивања), намиња́њеl наме̨ња́ње за прика́јање (здравице) и др.; Благоје Чоботин пише у раду Елементи традицијске културе Срба у селима у долини Мориша: годишњи изиклус о обичајима православних Срба из шест села из Поморишја, а то су: Чанад, Семпетар, Наћвала, Саравола, Кетфељ и Варјаш. У раду су обичајне праксе и верски ритуали који се светкују у православној цркви на празницима: Помен светих 40. мученика Севастијских или Младенци, Беле покладе, Благовести, Тодорова субота, Лазарева субота - Врбица, Велика недеља, Васкрсење Господа Исуса Христа, Ђурђевдан, Спасовдан, Духови, Ивањдан, Петровдан, Илиндан, Преображење Господње, Усековање, Божићне покладе, Варварица, Туциндан, Бадњидан, Божић и Богојављење.

Часопис: Исходишта 4, Темишвар/Ниш 2018. 
- На Западном универзитету у Темишвару, 19-21. октобра 2018. године одржан је 5. међународни научни скуп Матерријална $и$ духовна култура Срба у мултиетничким срединама и/или периферним областима / Cultura materială şi spirituală a sârbilor din regiunile multietnice şi/sau periferice на којем су учествовали универзитетски професори, научници и истраживачи из Румуније (Букурешт, Решица и Темишвар), Србије (Бања Лука, Београд, Косовска Митровица, Крагујевац, Ниш, Нови Сад и Сремска Митровица) и Црне Горе (Никшић).

Радови србиста из Румуније: у раду Istoria milenară a sârbilor din Banat (Prin prisma manuscriselor, transumpturilor şi a notelor din perioadă anilor 1010-1954) [Хиљадугодишња историја Срба у румунском Банату (На основу оригиналних рукописа, записа и преписа који се односе за период 10101954. године)] Иван Бирта доноси најраније потврде о присуству Срба у румунском Банату, ослањајући се на 18 све до данас необјављених докумената који се чувају у карашевским архивима (архиви Бирта, феудални Балкан). „Ови рукописи - пише аутор - одражавају реално стање на терену, сходно записима Румунске православне митрополије, и они се односе на период 1010-1954. године“; својим прилогом Породииа Дамаскин од Немета Саша Јашин наставља истраживање српског племства у Банату и задржава се на нешто мању племићку породицу Дамаскин, која скоро да је исчезла са историјске позорнице. „Српско-цинцарско племство - пише аутор - одиграло је значајну улогу у оквиру Хабзбуршке монархије, те је од велике важности да се свакој племићкој породици укаже пажња“. Аутор доноси податке о поседима породице Дамаскин, о заклади Стефана I Дамаскина у износу од 15.250 форинти, о породици Дамаскин од Немета, а у прилогу приказује нам опис закладе и прилога Стефана пл. Дамаскина од Немета и његове породице и диптихон упокојених чланова породица Стефана пл. Дамаскина од Немета; Жива Милин у раду Из наше заоставштине: писии и књиге расправља о валоризацији српске заоставштине настале на данашњој територији Румуније. Валоризовани су писци и рукописне и штампане књиге из наше прошлости. „Аутори тих рукописних и штампаних књига - пише аутор - су Срби са савремене територије Румуније, искључиво из Баната и Ердеља, а и они рођени ван ове територије у доба Аустроугарске и службено постављени у овдашње српске институције, а неки од њих остали у њима и после поделе Баната 1919. године и постали румунски грађани“. Ова је валоризација извршена у облику монографија, превода и приређених издања; заједничка књижевна студија Дух српске модерне у Темишвару Тодор Манојловић и Милош Црњански Октавије Неделку и Лидије Чолевић посвећена је двојици песника Војвођана родом из Баната, „песницима другог таласа српског модернизма, експресионизма“, тесно везаним за Темишвар. Милош Црњански је детињство и осмогодишње школовање провео у 
Темишвару, од 1896. до 1912. године, а Тодор Манојловић је у Темишвару радио као новинар, позоришни и музички критичар за немачки лист „Neue Temeswarer Zeitung" и проводио време у круговима авангардних мађарских уметника и књижевника, од 1911. до 1912. године. Оба песника „стваралачки идентитет од првих корака налазе у разноврсности културних миљеа који су их формирали: српском, мађарском, немачком, британском, италијанском и румунском“. На крају студије, након приказаних података из животописа и стваралаштва двојице писаца, ауторке пишу овако: „Сасвим је извесно да сјај дела Милоша Црњанског у Темишвару не пролази и да у поређењу са њим, Тодор Манојловић носи „етикету заборављеног писца“ у Темишвару. Стога овим радом покушавамо да исправимо неправду према овом ствараоцу који је допринео расветљавању српско-румунско-мађарских веза у Темишвару, а који као да је на тренутак заборавио на њега“; антрополошки рад Структурне и творбене карактеристике карашевске антропонимије из прве половине XVII века Михаја Н. Радана је знатан допринос проучавању историјске антропонимије Карашевака. У њему аутор анализира карашевска презимена из спискова босанских фрањеваца састављених у петој деценији XVII века. Поред структурне и творбене анализе презимена, аутор истиче да „истовремено, извршена је и компаративна анализа презимена забележених средином XVII века са садашњим презименима и надимцима карашевског живља, са циљем да се расветли правац еволуције карашевске антропонимије и, имплиците, да се разоткрију промене до којих је дошло у етничкој структури карашевске енклаве почев од друге половине XVII века до данас“; у раду Културно-уметничка друштва српске мањине из Румуније у међуратном периоду Миодраг Ћурушкин је поставио себи за циљ да „представи активност неколико културно-уметничких и добротворних друштава, као и читаоница из Темишвара и околних средина“. Аутор наводи 16 постојећих друштава у Темишвару и у српским селима у румунском делу Баната, а доноси податке о следећим: Темишварска добротворна задруга источно-православних српкиња, основана 1900. године, Коло српске омладине, основано 12. маја 1931, Српско читалачко друштво из Ченеја, основано 17. децембра 1932. године, Српска читаоница из Сараволе, основана 21. јануара 1933. године; Миљана Радмила Ускату пише у прилогу Нека традиционална јела у Карашеву да су нека од карашевских јела тесно повезана са месним традиционалним обредима и обичајима. Ауторка приказује следећа јела: тига́њак, ки́сељииа, пи́та, трупии, то́ртањи, перишо́ре, по́друп, промпи́ри у типси́ји, наћ' '́́кано ја́јųе, ко́мкарище и др.; Маца Царан Андрејић посветила је рад Славомир Гвозденовић - књижевно дело у духу сриства савременом српском песнику, вишегодишњем главном уреднику часописа „Књижевни живот“, доктору филологије, професору на Одсеку за србистику Западног универзитета у Темишвару, преводиоцу и антологичару, поводом његове 65-годишњице. О животу, књижевној и научној делат- 
ности песника ауторка пише у следећим поглављима: „О писцу“, „Главне компоненте Гвозденовићеве поезије“, „Научни рад“ и „Закључак“. Ево и кратке оцене за песника и његову поезију: „Он је најсвестранији и стваралачким опусом најплоднији књижевник српске дијаспоре. Обим и вредност Гвозденовићевог опуса упућују да је он ту привилегију заиста заслужио“; последњи рад са овог научног скупа је Посмртни ритуали за покој душа уснулих код Срба у Кетфељу - Румунија Благоја Чоботина, у којем аутор описује посмртне обичаје и ритуале за покој душе уснулих у првих четрдесет дана, након сахране. Ти обичаји и ритуали су се сачували код Срба у Кетфељу све до краја прошлога века. Ево неколико обичаја и ритуала: помана или даћа након полагања тела покојника у гроб, помана или парастос на недељу дана (девет дана од упокојења), на иест недеља (четрдесетодневна помана), на пола године, на годину дана, а потом из године у годину, ношење извор-воде за покојника и др.

Часопис Ийходишта 5, Темишвар/Ниш, 2019.

Жива Ђ. Милин

\title{
СЕРБИСТЫ ИЗ РУМЫНИИ НА МЕЖДУНАРОДНЫХ СИМПОЗИУМАХ В АРАДЕ, ТИМИШОАРЕ (РУМЫНИЯ) И НИШЕ (СЕРБИЯ) 2005-2018
}

\begin{abstract}
Резюме
В работе обсуждены 15 международных симпозиумов, которые состоялись в течение первых двух десятилетий XXI века в Араде, Тимишоаре и Нише. Из них выделяем: Dialoguri interculturale. 50 de ani de slavistică timişoreană/ Међукултурни дијалози. Пола века темишварске славистике/Межкультурнье диалоги. 50 лет тимишоарской славистике (2007), Државотворна идеја тројице српских великана: грофа Ђорђа Бранковића, Доситеја Обрадовића и Саве Текелије [Государственно-созидательная идея трех сербских великанов: графа Георгиа Бранковича, Доситея Обрадовича и Савы Текелии] (2011), Eycmaхија Арсић, писаи и мецена [Евстахия Арсич, писатель и мецена] (2013), Црњански у Темишвару [Цернянски в Тимишоаре] (2014), Арадска тврђава - логор за српске интернирие у Првом светском рату [Арадская крепость лагерь для сербских пленных в Первой мировой войне] (2014), Материјална и духовна култура Срба у мултиетничким срединама и/или периферним областима / Cultura materială şi spirituală a sârbilor din regiunile multietnice şi/ sau periferice [Материальная и духовная культура сербов в мултиэтнических средах и/или периферных областях] (2014-).Авторы сообщенных рефератов, работ и статей - профессора, ученые, писатели, научные исследователи и др.,
\end{abstract}


а их темы выбраны из истории, диалектологии, литературы , фольклора, топонимии, ономастики, сербско-румынского сожительства итд.

Ключевые слова: автор, исследователь, писатель, писать, профессор, работа, сборник, сербист, симпозиум, ученый. 